\title{
PENGARUH PEMBERIAN FRAKSI ETIL ASETAT EKSTRAK ETANOL 70\% HERBA PEGAGAN TERHADAP PENYEMBUHAN LUKA BAKAR PADA TIKUS PUTIH JANTAN
}

\author{
EFFECT OF ETHYL ACETATE FRACTION ETHANOL 70\% \\ EXTRACT OF Centella asiatica $L$. IN HEALING BURN \\ WOUNDED ON ALBINO MALE RAT
}

\author{
Dwitiyanti, Sediarso, Ade Andar Kusuma \\ Fakultas Farmasi dan Sains Universitas Muhammadiyah Prof. DR. HAMKA \\ Islamic Center, Jl. Delima II/IV, Perumnas Klender, Jakarta Timur \\ Email: dwity.farmasi@gmail.com
}

\begin{abstract}
ABSTRAK
Luka bakar merupakan respon kulit dan jaringan subkutan terhadap suhu untuk memperbaiki jaringan akibat luka bakar digunakan pegagan. Herba pegagan mempunyai khasiat untuk memperbaiki jaringan granulasi kulit dan penyembuh luka. Penelitian ini bertujuan untuk mengetahui pengaruh pemberian fraksi etil asetat herba pegagan terhadap penyembuhan luka bakar. Hewan uji yang dipakai adalah tikus putih jantan yang dibagi menjadi 6 kelompok perlakuan. Kelompok I (kontrol normal), kelompok II (kontrol negatif), kelompok III (kontrol positif) dilukai dan diberi povidon iodium, kelompok IV, V dan VI dilukai dan diberi fraksi etil asetat ekstrak etanol herba pegagan $0,37 \%, 0,93 \%$ dan $1,49 \%$. Punggung tikus diinduksi dengan logam panas dengan suhu $105^{\circ} \mathrm{C}$. Pengamatan dilakukan 2 hari sekali selama 14 hari. Data yang didapat diuji secara statistik dengan uji ANOVA dua arah yang dilanjutkan dengan uji Tukey. Hasilnya adalah kelompok konsentrasi $0,93 \%$ dan konsentrasi $1,49 \%$ memiliki khasiat setara dengan kelompok kontrol positif.
\end{abstract}

Kata Kunci :Luka bakar, herba pegagan, fraksi etil asetat

\begin{abstract}
Burn wounded is a response of skin and subcutaneous tissue to temperatures for tissue repair due to burns Centella asiatica, has efficacy for repair granulation tissue of skin and healing wound. The research aims is to prove the effect of ethyl acetate fraction of centella asiatica for healing burn wounded. The research used Male albino rat, that were divided into 6 group. The group I, II, III in subsquently as normal, negative and positive, group $I V, V$ and $V I$ was wounded and given a $0.37 \%, 0.93 \%$, and $1.49 \%$ concentration of ethyl acetate fraction of ethanol extract of Centella asiatica herb. Back of mouse induced by hot metal with
\end{abstract}


temperature $105^{\circ} \mathrm{C}$. Observations were made every 2 days for 14 days. The result was analyzed using two-way ANOVA and Tukey test. It can be concluded that $0.93 \%$ and $1.49 \%$ concentration has equivalent efficacy with positive group.

Keyword : Burn wounded, centella asiatica herb, ethyl acetate fraction

\section{PENDAHULUAN}

Pegagan adalah tanaman yang tumbuh di seluruh Indonesia serta daerah-daerah beriklim tropis pada umumnya. Pegagan dapat tumbuh mulai di dataran rendah hingga ketinggian $2500 \mathrm{~m}$ dpl. Pegagan juga tumbuh di tempat lembab dan subur seperti padang rumput, di antara batu-batu dan di tepi jalan. (BPOM RI, 2010). Pegagan mengandung triterpenoid asiatikosida, madekasosida, asam asiatat, asam madekasat, asam indosentoat, bayogenin, asam euskapat, flavonoid, kaempferol, kuersetin, saponin, sentelasapogenol A, B, dan D, poliasetilen, kadiyenol, sentelin, asiatisin, dan sentelisin. Pegagan secara tradisional banyak digunakan untuk penyakit kulit. Disamping itu pegagan juga digunakan untuk mengobati sakit perut, batuk, batuk berdarah, penambah selera makan, asma, dan penyembuh luka (BPOM RI, 2010).
Luka bakar merupakan respons kulit dan jaringan subkutan terhadap suhu. Luka bakar dengan ketebalan parsial merupakan luka bakar yang tidak merusak epitel kulit atau hanya merusak sebagian dari epitel. Biasanya dapat pulih dengan penanganan konservatif. Luka bakar dengan ketebalan penuh merusak sumber-sumber pertumbuhan kembali epitel kulit dan bisa membutuhkan eksisi dan cangkok kulit jika luas (Grace and borley, 2007).

Berdasarkan studi pustaka senyawa yang berperan untuk pengobatan luka bakar pada herba pegagan adalah asiaticoside yang merupakan senyawa glikosida triterpenoid dan berdasarkan tingkat kepolarannya senyawa ini berada pada fase semipolar menuju polar (Rismana et al., 2013), oleh karena itu dilakukan penelitian lebih lanjut dengan menggunakan fraksi etil asetat herba pegagan dalam penyembuhan luka bakar. 
Berdasarkan hal tersebut maka dilakukan penelitian uji aktivitas penyembuhan luka bakar fraksi etil asetat ekstrak etanol herba pegagan terhadap tikus putih jantan.

Penelitian ini bertujuan untuk mengetahui aktivitas penyembuhan luka bakar fraksi etil asetat ekstrak etanol herba pegagan (Centella asiatica (L.) Urb.) terhadap luka bakar pada punggung tikus putih diinduksi logam panas.

\section{METODE PENELITIAN}

Alat yang digunakan antara lain: kandang untuk hewan uji, perlengkapan tempat makan dan minum tikus, neraca analitik (OHAUS), mortir, stamper, kaca arloji, jangka sorong, kapas pisau cukur dan keping logam.

Bahan yang dibutuhkan antara lain pegagan yang diperoleh dari Balai Penelitian Tanaman Rempah dan Obat (BALITRO), etanol 70\%, n-heksan, etil asetat, phenobarbital injeksi, akuades, hewan percobaan tikus putih jantan galur SD (Sprague Dawley) berumur 2-3 bulan, berat badan 150-200 gram.
Herba pegagan diperoleh dari Balitro dan Determinasi tanaman dilakukan di Pusat Botani Herbarium Bogoriense LIPI Cibinong, Bogor.

Herba pegagan yang telah dikumpulkan dibersihkan dari pengotor dengan air bersih. Selanjutnya dtimbang sebagai berat segar sebesar $4 \mathrm{~kg}$, kemudian dikeringkan dengan cara menjemurnya di panas matahari menggunakan alas (Darwati, 2012). Sampel yang telah kering diserbuk dengan blender. Serbuk yang diperoleh diayak dengan pengayak mesh 60 lalu disimpan dalam wadah bersih dan tertutup rapat.

Serbuk kering sebanyak $1 \mathrm{~kg}$ dimaserasi dengan etanol $70 \%$ sebanyak 10 liter, lalu direndam selama 3 hari disertai dengan pengadukan, setelah 3 hari dilakukan penyaringan, dan ampasnya dimaserasi kembali dengan etanol $70 \%$ dengan menggunakan prosedur yang sama. Maserasi dilakukan sebanyak tiga kali. Hasil maserasi diuapkan menggunakan vacuum rotary evaporator hingga diperoleh ekstrak kental sebesar 220 gram. (Depkes RI, 2008). 
Ekstrak kental etanol $70 \%$ dimasukkan ke dalam corong pisah kemudian difraksinasi dengan $n$ heksan (1:1), kocok selama \pm 15 menit. Setelah itu didiamkan sampai terbentuk lapisan n-hexan dan lapisan etanol 70\%. Lapisan nheksan dipisahkan dari lapisan etanol 70\%. Kemudian difraksinasi lapisan etanol $70 \%$ dengan etil asetat (1:1), dikocok selama \pm 15 menit. Kemudian ditambahkan air hangat secukupnya, kocok selama \pm 15 menit. Lalu didiamkan beberapa saat hingga terbentuk lapisan etil asetat dan lapisan etanol 70\%. Lapisan etil asetat dipisahkan dengan lapisan etanol. Lapisan tersebut disebut sebagai fraksi etil asetat. Fraksi etil asetat diuapkan dengan rotary evaporator hingga diperoleh fraksi kental. Kemudian fraksi tersebut dikeringkan dengan oven pada suhu $50^{\circ} \mathrm{C}$

Pada penelitian ini, digunakan obat pembanding povidon iodium. Konsentrasi povidon iodium yang dipakai adalah 10\%. Penelitian ini menggunakan 3 variasi konsentrasi fraksi etil asetat herba pegagan, yaitu konsentrasi $\quad 0,37 \%, \quad$ konsentrasi $0,93 \%$, dan konsentrasi $1,49 \%$.

Hewan uji dibagi menjadi 6 kelompok dengan masing-masing kelompok terdiri dari 4 hewan uji. Kelompok I tidak dilukai (kelompok kontrol normal), kelompok II hanya dilukai (kelompok kontrol negatif), kelompok III dilukai dan diberi fraksi povidon iodium (kontrol positif), kelompok IV dilukai dan diberi fraksi etil asetat herba pegagan konsentrasi $0,37 \%$, kelompok V dilukai dan diberi fraksi etil asetat herba pegagan konsentrasi $0,93 \%$, kelompok VI dilukai dan diberi fraksi etil asetat herba pegagan konsentrasi $1,49 \%$.

Pembuatan luka bakar dilakukan dengan cara menempelkan logam yang telah dipanaskan sebelumnya di dalam oven dengan suhu $105^{\circ} \mathrm{C}$, setelah itu ditempelkan di punggung tikus yang sebelumnya telah dicukur rambutnya terlebih dahulu selama 10 detik (Widianingtias, 2010).

Pemberian fraksi etil asetat herba pegagan dilakukan sehari setelah pembuatan luka sampai hari ke-13 pada waktu pagi hari dengan 
cara dioleskan rata pada punggung tikus yang telah dibuat luka.

Pengukuran dilakukan dengan cara mengamati luas daerah luka dan persentase penyembuhan luka, dengan cara mengukur diameter luka yang diukur pada arah vertikal, horizontal dan kedua diagonal. Pengukuran luka dilakukan sehari setelah pembuatan luka dan dilanjutkan 2 hari berikutnya selama 14 hari.

Data yang digunakan untuk analisis statistik adalah data diameter akhir luka bakar pada saat pengukuran hari ke-2 sampai hari ke14. Data ditentukan terlebih dahulu normalitas dan homogenitasnya dari setiap data dan dilanjutkan dengan uji ANOVA dua arah dengan taraf signifikansi $95 \% \quad(\alpha=0,05)$.

Kemudian dilihat ada tidaknya perbedaan yang bermakna, jika terdapat perbedaan yang bermakna maka dilanjutkan dengan uji tukey.

\section{HASIL DAN PEMBAHASAN}

Uji identifikasi dilakukan untuk mengetahui kandungan kimia yang terdapat dalam herba pegagan. Hasil penapisan fitokimia dapat dilihat pada tabel I.

Hasil penyembuhan luka bakar pada tikus putih jantan dengan pemberian fraksi etil asetat herba pegagan dilakukan dari hari kedua hingga hari ketiga belas. Hasil pengamatan berupa diameter luka bakar selama 14 hari pengamatan dapat dilihat pada tabel II.

Tabel I. Penapisan fitokimia herba pegagan

\begin{tabular}{llcc}
\hline No. & \multicolumn{1}{c}{ Metabolit sekunder } & \multicolumn{2}{c}{ Hasil } \\
\cline { 3 - 4 } & & Serbuk kering & Fraksi etil asetat \\
\hline 1 & Alkaloid & + & + \\
2 & Flavonoid & + & + \\
3 & Saponin & + & + \\
4 & Tanin & + & + \\
5 & Steroid dan Terpenoid & + & + \\
\hline
\end{tabular}

Tabel II. Diameter luka bakar tiap kelompok (cm) 


\begin{tabular}{cccccc}
\hline Hari & $\begin{array}{c}\text { Kontrol } \\
\text { Positif }\end{array}$ & $\begin{array}{c}\text { Kontrol } \\
\text { Negatif }\end{array}$ & $\begin{array}{c}\text { Konsentrasi } \\
\mathbf{0 , 3 7 \%}\end{array}$ & $\begin{array}{c}\text { Konsentrasi } \\
\mathbf{0 , 9 3 \%}\end{array}$ & $\begin{array}{c}\text { Konsentrasi } \\
\mathbf{1 , 4 9 \%}\end{array}$ \\
\hline 2 & 1,7590 & 1,9336 & 1,9336 & 1,9501 & 1,8289 \\
4 & 1.4496 & 1.7925 & 1,7626 & 1,6909 & 1,6593 \\
6 & 1.1387 & 1.6668 & 1,5311 & 1,4487 & 1,3029 \\
8 & 0,8786 & 1,5257 & 1,2377 & 1,1197 & 0,9678 \\
10 & 0,7055 & 1,4495 & 0,9608 & 0,7443 & 0,5561 \\
12 & 0.2730 & 1,2356 & 0,6443 & 0,3800 & 0,2310 \\
14 & 0,0850 & 0,8713 & 0,3550 & 0,1121 & 0 \\
\hline
\end{tabular}

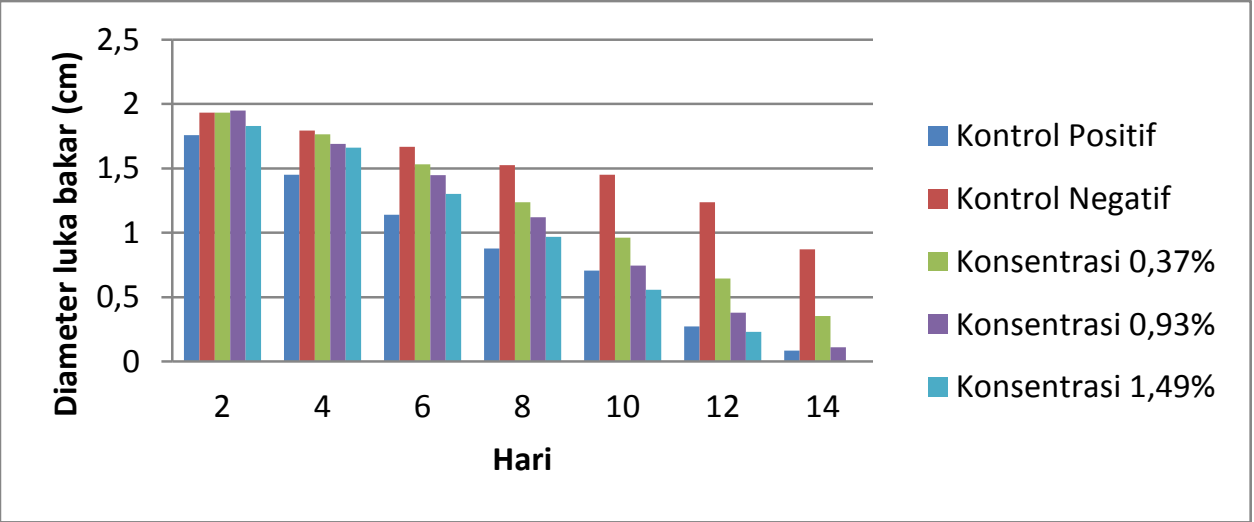

Gambar 1. Grafik batang hubungan antara diameter luka bakar terhadap hari

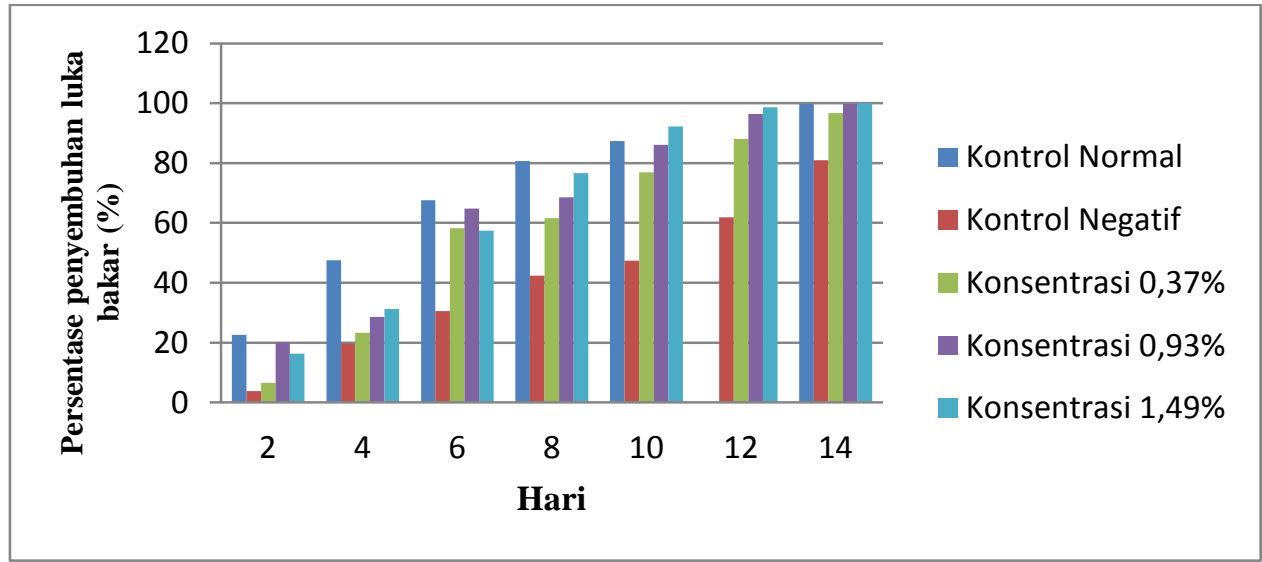

Gambar 2. Grafik batang hubungan antara persentase akhir penyembuhan luka bakar terhadap hari 
Tabel III. Persentase penyembuhan luka bakar tiap kelompok (\%)

\begin{tabular}{cccccc}
\hline Hari & $\begin{array}{c}\text { Kontrol } \\
\text { Positif }\end{array}$ & $\begin{array}{c}\text { Kontrol } \\
\text { Negatif }\end{array}$ & $\begin{array}{c}\text { Konsentrasi } \\
\mathbf{0 , 3 7 \%}\end{array}$ & $\begin{array}{c}\text { Konsentrasi } \\
\mathbf{0 , 9 3 \%}\end{array}$ & $\begin{array}{c}\text { Konsentrasi } \\
\mathbf{1 , 4 9 \%}\end{array}$ \\
\hline 2 & 22,63 & 3,8 & 6,60 & 20,11 & 16,33 \\
4 & 47,54 & 19,59 & 23,32 & 28,56 & 31,15 \\
6 & 67,59 & 30,52 & 58,17 & 64,83 & 57,39 \\
8 & 80,63 & 42,35 & 61,54 & 68,61 & 76,57 \\
10 & 87,35 & 47,42 & 76,91 & 86,11 & 92,25 \\
12 & 97,95 & 61,82 & 88,09 & 96,38 & 98,64 \\
14 & 99,77 & 80,89 & 96,64 & 99,67 & 100 \\
\hline
\end{tabular}

Untuk melihat seberapa besar aktivitas fraksi etil asetat herba pegagan dalam penyembuhan luka bakar, maka data diameter luka bakar tiap kelompok perlakuan tersebut kemudian diubah dalam bentuk persentase penyembuhan luka bakar yang dapat dilihat pada tabel III.

Pada tabel rata-rata diameter luka bakar didapatkan bahwa pada kelompok yang diberi konsentrasi $0,37 \%, \quad 0,93 \%$, dan konsentrasi $1,49 \%$ fraksi etil asetat ekstrak etanol herba pegagan dan kontrol positif menunjukkan adanya aktivitas penyembuhan luka bakar yang lebih baik dibandingkan kontrol negatif. Hal ini dibuktikan dengan besarnya persentase penyembuhan luka pada tiap kelompok perlakuan dan kelompok kontrol positif dibandingkan dengan persentase kelompok kontrol negatif.
Simplisia herba pegagan didapat dari budidaya tanaman obat di BALITTRO Bogor. Hal ini dilakukan untuk menghindari faktorfaktor yang dapat mempengaruhi hasil percobaan serta untuk mendapatkan simplisia dengan kualitas yang baik. Pemeriksaan kandungan kimia fraksi dilakukan untuk mengetahui senyawa aktif yang terdapat pada simplisia herba pegagan. Dari hasil pemeriksaan bahwa herba pegagan mengandung alkaloid, flavanoid, tanin, saponin, steroid dan terpenoid.

Herba pegagan yang didapat kemudian dikeringkan di bawah sinar matahari serta diberi alas (Darwati, 2012). Pengeringan bertujuan untuk mengurangi kadar air yang terdapat di simplisia, sehingga dapat disimpan dalam waktu yang lebih lama. Selain itu pengeringan juga mencegah simplisia agar tidak berjamur dan 
kandungan kimia zat yang berkhasiat tidak berubah karena proses fermentasi.

Metode ekstraksi yang digunakan adalah metode maserasi. Metode ini dipilih dengan tujuan agar menghindari rusaknya senyawasenyawa yang terdapat di dalam simplisia akibat pemanasan. Pelarut yang digunakan untuk maserasi ini adalah etanol $70 \%$. Pemilihan etanol $70 \%$ sebagai pelarut karena etanol adalah pelarut yang mudah melarutkan senyawa-senyawa organik yang ada pada simplisia, selain itu etanol juga dapat menghambat pertumbuhan mikroorganisme yang mengakibatkan rusaknya kandungan simplisia. Maserat yang didapat kemudian dipekatkan dengan menggunakan vacum rotary evaporator. Pemekatan bertujuan untuk meningkatkan kandungan ekstrak herba pegagan dengan mengurangi kadar air dan mengurangi sisa pelarut pada saat proses maserasi.

Fraksi herba pegagan dibuat dengan cara pemisahan ekstraksi berdasarkan tingkat kepolaran yakni berturut-turut menggunakan pelarut n-heksan, dan etil asetat. Proses ini bertujuan untuk meningkatkan kandungan senyawa yang dikehendaki dengan menghilangkan atau memisahkan senyawa yang tidak dikehendaki semaksimal mungkin, sehingga diperoleh ekstrak yang lebih murni.

Pemilihan povidon iodium sebagai bahan pembanding adalah karena povidon iodium merupakan salah satu zat yang umum digunakan sebagai pengobatan pada penderita luka. Povidon iodium juga bersifat antiseptik, sehingga dapat mempercepat dalam penyembuhan pada luka.

Luka bakar dibuat dengan cara menempelkan logam panas yang dipanaskan dalam oven dengan suhu $105^{\circ} \mathrm{C}$ ke punggung tikus. Luka akan berbentuk oval setelah 24 jam. Hal ini terjadi akibat adanya gerakan yang dilakukan oleh hewan uji, sehingga mengakibatkan luka bakar menjadi tertarik di bagian atas dan bawah. Pada 24 jam pertama setelah luka dibuat akan terjadi proses inflamasi dan proses epitelisasi. Pengukuran diameter luka bakar 
dilakukan 1 hari setelah dilakukan pembuatan luka bakar kemudian dilanjutkan selama 2 hari sekali sampai hari ke-14. Hari ke-2 sampai hari ke-14 adalah fase dimana terjadinya granulasi akibat pembentukan serat kolagen yang akan bertautan pada tepi luka.

Pada hari ke-2 hingga hari ke-13 dilakukan pemberian fraksi etil asetat herba pegagan untuk kelompok perlakuan dan baku pembanding povidon iodium pada kelompok kontrol positif. Pembuatan fraksi etil asetat herba pegagan dilakukan setiap 2 hari sekali. Hal ini ditujukan untuk menjaga kondisi sediaan agar tetap stabil sehingga diharapkan dapat memaksimalkan proses penyembuhan luka bakar.

Data hasil diameter akhir luka bakar yang diperoleh terlebih dahulu diuji normalitas dan homogenitasnya dan dilanjutkan dengan analisa menggunakan uji statistik ANOVA dua arah, dan apabila ada perbedaan yang bermakna maka dilanjutkan dengan uji Tukey. Data hasil diameter akhir luka bakar kemudian dirubah pula kedalam persentase penyembuhan luka untuk melihat seberapa aktivitas penyembuhan luka bakar yang dihasilkan oleh fraksi etil asetat herba pegagan.

$$
\text { Pada uji lanjut Tukey }
$$
menunjukkan bahwa terdapat perbedaan bermakna dari kelompok kontrol positif, kelompok konsentrasi 0,93\%, dan kelompok konsentrasi 1,49\% dengan kelompok kontrol negatif, dan tidak terdapat perbedaan bermakna antara kelompok konsentrasi $0,93 \%$ dan kelompok konsentrasi $1,49 \%$ dengan kontrol positif. Hal ini didukung dengan besarnya aktivitas penyembuhan luka bakar pada kelompok kontrol positif, kelompok konsentrasi $0,93 \%$ dan kelompok konsentrasi 1,49\%.

Dari hasil data persentase penyembuhan luka bakar didapatkan bahwa hari ke-14 di tiap kelompok mengalami persentase penyembuhan luka bakar yang tinggi, dan pada hasil uji anova dua arah menunjukkan bahwa tidak ada perbedaan bermakna antara hari ke14 dan hari ke-12 sehingga dapat disimpulkan bahwa hari ke-12 adalah hari yang optimum dalam penyembuhan luka bakar. Hal ini didukung pula dari besarnya 
persentase penyembuhan luka bakar dari semua kelompok perlakuan dan kelompok kontrol positif dan kontrol negatif pada hari ke-12.

\section{KESIMPULAN}

Berdasarkan hasil penelitian, dapat disimpulkan bahwa fraksi etil asetat herba pegagan (Centella asiatica (L.) Urb.) memiliki aktivitas dalam penyembuhan luka bakar. Konsentrasi terbaik terdapat pada konsentrasi $0,93 \%$ dan $1,49 \%$ yang sebanding dengan kontrol positif dalam penyembuhan luka bakar. Pada persentase penyembuhan luka bakar didapatkan hari ke-12 adalah hari yang optimum dalam proses penyembuhan luka bakar yang ditunjukkan dengan besarnya hasil persentase penyembuhan luka bakar pada semua kelompok perlakuan.

\section{DAFTAR PUSTAKA}

Badan Pengawas Obat dan Makanan Republik Indonesia, 2010, Serial Data Ilmiah Terkini Tumbuhan Obat, Penerbit Badan Pengawas Obat dan Makanan Republik Indonesia. Jakarta. Hlm. 1-4.

Darwati I., 2012, Budidaya dan Pasca Panen Pegagan (Centella asiatica), Balai
Penelitian Tanaman Rempah dan Obat. Bogor.

Depkes RI, 2008, Farmakope Herbal Edisi I, Departemen Kesehatan. Jakarta: Hlm. 174.

Grace P A., Borley N R., 2007, At a Glance Ilmu Bedah Edisi 3, Terjemahan: Vidhia Umami. Penerbit Erlangga, Jakarta: Hlm. 87.

Rismana E, Rosidah I, Prasetyawan Y, Bunga O, Erna Y., 2013, Efektivitas Khasiat Pengobatan Luka Bakar Sediaan Gel Mengandung Fraksi Ekstrak Pegagan Berdasarkan Analisis Hidroksiprolin dan Histopatologi Pada Kulit Kelinci. Buletin Penelitian Kesehatan, vol. 41. Pusat Teknologi Farmasi dan Medika, Badan Pengkajian dan Penerapan Teknologi, Jakarta: Hlm. 46

Widianingtyas D., 2010, Pengaruh Perawatan dengan Ekstrak Daun Pegagan (Centella asiatica) dalam Mempercepat Penyembuhan Luka Bakar Derajat Dua Dangkal Pada Tikus Putih (Rattus novergicus) Strain Wistar, Skripsi, Universitas Brawijaya, Malang. 